\title{
$\nabla$ \\ Assessment of Health Awareness and Nutritional Knowledge of the Dyslipidemia Subjects
}

\author{
IJCRR \\ Section: Healthcare \\ ISI Impact Factor \\ (2019-20): 1.628 \\ IC Value (2019): 90.81 \\ $\operatorname{SJIF}(2020)=7.893$ \\ (c) (7) (3) \\ Copyright@IJCRR
}

\section{Shivakumara C.S ${ }^{1,2}$, Satish A2, Usha Devi C}

'Department of Food and Nutrition and Research Centre, Smt V.H.D Central Institute of Home science, Bangalore University,

Bangalore-5600o Karnataka, India; ${ }^{2}$ Department of Clinical Nutrition and Dietetics, Sri Devaraj Urs Academy of Higher Education and Research, Tamaka, Kolar- 563103, Karnataka, India.

\section{ABSTRACT}

Introduction: Dyslipidemia is one of the major risk factor for atherosclerosis and related cardiovascular diseases. Evaluating health behavior patterns and knowledge regarding food and nutrients after diagnosis may help improve the management of dyslipidemia.

Objective: The study aimed to assess the health awareness and nutrition knowledge among Dyslipidemia subjects.

Methods: The area chosen for the studies was public sector company hospitals from Bangalore region. It was the study of the cost-effectiveness of health awareness and nutritional knowledge. The random sample of 400 aged between 31-60 years was recruited from the Public sector company hospitals. The information obtained on a) socio-economic profile and b) assessment of health awareness and nutritional knowledge using a questionnaire. Awareness comprising of 14 statements and knowledge using 16 statements with 'Yes' or 'No' options.

Results: Most of the subjects were found between 31-40 years (42.8 \%), 76.5\% were males and $23.5 \%$ were females. Females respondents had higher nutrition knowledge (48.9\%) and health awareness $(55.8 \%)$ than their male's counterparts (44\%) and $(48 \%)$ respectively. 41-50 years (64\%) had the unfavourable level of Health Awareness and inadequate level (69.6\%) of nutritional knowledge. Unfavourable level of Health Awareness inadequate level of nutritional knowledge was observed irrespective of the educational and occupational status of the respondents compared to those working as a staff nurse had a moderate level of Health Awareness and nutritional knowledge.

Conclusion: Health awareness and nutritional knowledge of among Dyslipidemia subjects females found higher than males however found inadequate. Creating health awareness and nutritional knowledge alone may not be an adequate amount of to progress health status in patients with dyslipidemia.

Key Words: Awareness, Dyslipidemia, Food, Health, knowledge, Nutrients, Socio-economic

\section{INTRODUCTION}

Cardiovascular disease (CVD) is one of the biggest causes of death globally. Cardiovascular disease occurs typically due to atherosclerosis of bulky and medium-sized arteries and dyslipidemia is one of the most important causative factors. Lowering lipids through nutritional intervention or pharmacological treatment has been shown to decrease the occurrence of atherosclerotic events. ${ }^{1}$ Approximately 31.8 million peoples were living with coronary artery disease (CAD) in India alone. ${ }^{2}$ The Cardiovascular disease tends to occur at the youths in India with $52 \%$ of CVD deaths occurring under the age of 70 years and $10 \%$ of heart attacks happening in subjects with $<40$ years of age. Dyslipidemia is one of the major adjustable causative factors for atherosclerosis and related cardiovascular diseases, including coronary heart disease, cerebral stroke, and myocardial infarction. Even though significant technological improvements in the health care and treatment there will be increasing in the lifestylerelated chronic diseases around the world (e.g., type-2 diabetes, cardiovascular disease and obesity) since the last decades. ${ }^{3}$ Presently, the most important causes for mortality in the worldwide could be controlled by appropriate nutrition, daily physical exercise, and a healthy lifestyle that includes leisure time, stress management, and personal and environmental care $^{4}$ such diseases are called non-communicable diseases (NCDs). Accordingly, an unhealthy diet has been

\section{Corresponding Author:}

Dr. Usha Devi C, Associate Professor, Department of Food and Nutrition and Research Centre, Smt V.H.D Central Institute of Home science, Bangalore University, Bangalore, Karnataka, India; Phone: 9900131196; Email: drushaharish@gmail.com

ISSN: $2231-2196$ (Print)

Received: 23.07 .2020
ISSN: 0975-5241 (Online)

$$
\text { Revised: } 02.10 .2020
$$

Accepted: 19.11 .2020

Published: 03.02 .2021 
identified as a chief causative factor for the global increase in chronic non-communicable diseases, such as coronary artery disease, cardiovascular disease, cancer, diabetes and obesity. A large proportion of these diseases can be avoided as they are either initiated or accelerated by unhealthy nutrition in addition to other etiologies. ${ }^{5,6}$

Nutrition and health education is a successful method to improvement the dietary practice and provides great chance to learn about the essentials of nutrition for health and to take steps to improve the quality of their diets. ${ }^{7}$ The nutrition knowledge has an intensively control on food selection and parallel with nutrient intake. ${ }^{8}$ Knowledge is varies broadly among different geographical locations ${ }^{6}$ which may give clear evident variability in the food choices within the populations represented by varying cultural backgrounds. ${ }^{9}$ The process by which nutrition knowledge converted into dietary behaviours is the complicated and hypothetical way of food selection suggest that individuals awareness about food and nutrients are the key determinants of food choices. ${ }^{10} \mathrm{How}-$ ever, Self- consciousness of the importance of balanced meals (henceforth suggested that nutritional awareness) can be viewed as a central factor that may control food choices and nutritional intake. ${ }^{11}$ Concerning food, knowledge on what should be eaten and the awareness of the importance of healthy food habits are the first steps in altering eating behaviour. From this perspective, an attempt was made in the current study to evaluate the Health awareness and $\mathrm{Nu}$ tritional knowledge of the Dyslipidemia subjects.

\section{MATERIALS AND METHODS}

\section{Selection of the samples}

A total of four hundred samples (male-n=306 and female$\mathrm{n}=96$ ) aged between 30 to 60 years with Dyslipidemia was randomly selected from public sector company hospitals in Bangalore city, Karnataka, based on the prevalence level of dyslipidemia at $95 \%$ of 1.96 confidence of intervals. Diagnosis of Dyslipidemia cut of the value of Total Cholesterol more than $>200$ or Low-Density Lipoprotein Cholesterol more than $>130$, secondary data was selected with the help of physician and cardiologist using available medical records. The study was approved by the Nutri-Explore Ethics Committee (NEEC BU 010 Ph.D/Project/2015-16).

\section{Nutritional knowledge and Health Awareness}

The subjects were instructed to complete the nutritional knowledge and health awareness questionnaire. The data were recorded during the working hours of the individual employees. Nutritional knowledge and health awareness were evaluated using a validated general questionnaire. The information obtained on a) Assessment of health awareness and b) Nutritional knowledge using a questionnaire. Health
Awareness comprising of 14 statements and nutrition knowledge measured using 16 statements with 'Yes' or 'No' options. Each response was given score namely.

Table 1: Response score

\begin{tabular}{lc} 
Response & Score \\
YES & 1 \\
NO & 0 \\
\hline
\end{tabular}

Based on the above score the total score for nutritional knowledge and health awareness was computed. The total score for health awareness was grouped into three categories namely unfavourable, moderate and favourable and for nutritional knowledge grouped in to inadequate, moderate and adequate (Table 2 and 3 ).

\begin{tabular}{|c|c|}
\hline Category & Score \\
\hline Unfavorable & $\leq 50 \%$ Score \\
\hline Moderate & $51-75 \%$ Score \\
\hline Favorable & $>75 \%$ Score \\
\hline
\end{tabular}

Table 3: Nutritional Knowledge Total Score

\begin{tabular}{lc} 
Category & Score \\
Inadequate & $\leq 50 \%$ Score \\
Moderate & $51-75 \%$ Score \\
Adequate & $>75 \%$ Score \\
\hline
\end{tabular}

\section{Statistical Data Analysis}

Collected data was consolidated, classified, tabulated and analyzed using SPSS version 20 (SPSS 20 is a comprehensive system for analyzing data) and office package windows 2010. The statistical test was used to analyze the data such as mean, standard deviation, chi-square test, and standard' test.

\section{RESULTS}

Table-1 represents higher parentages of the respondents were found in the age group of 31- 40 years $(42.8 \%)$ followed by 41-50 (28.0\%) and 51-60 years (28\%). Majority of dyslipidemia subjects were male $(75 \%)$. Fifty-one percentages of the patients were having two children followed by thirty-two per cent with one child. The finding reveals that majority of the respondents were Hindus (97.7) residing in the urban areas $(92.0 \%)$. Nuclear family trend $(91.8 \%)$ was observed among the respondents and their family income was found to be in the range of Rs 20,000 to 30,000 per month $(38.5 \%)$ (Table 4). 
Table 4: Demographic Profile of the Respondents

\begin{tabular}{|c|c|c|c|}
\hline \multirow[t]{2}{*}{ Characteristics } & \multirow[t]{2}{*}{ Category } & \multicolumn{2}{|c|}{ Respondents } \\
\hline & & Number & Per cent \\
\hline \multirow[t]{3}{*}{ Age group (years) } & $31-40$ & 175 & 42.8 \\
\hline & $41-50$ & 112 & 28.0 \\
\hline & $51-60$ & 113 & 28.2 \\
\hline \multirow[t]{2}{*}{ Gender } & Male & 306 & 75.0 \\
\hline & Female & 94 & 25.0 \\
\hline \multirow[t]{2}{*}{ Marital status } & Married & 400 & 100.0 \\
\hline & Unmarried & o & 0.0 \\
\hline \multirow[t]{4}{*}{ Number of children } & No & 27 & 6.8 \\
\hline & One & 129 & 32.2 \\
\hline & Two & 204 & 51.0 \\
\hline & Three & 40 & 10.0 \\
\hline \multirow[t]{2}{*}{ Place of Residence } & Rural & 32 & 8.0 \\
\hline & Urban & 368 & 92.0 \\
\hline \multirow[t]{3}{*}{ Type of family } & Nuclear & 361 & 91.8 \\
\hline & Joint & 24 & 6.0 \\
\hline & Extended & 9 & 2.2 \\
\hline \multirow[t]{3}{*}{ Religion } & Hindu & 391 & $97 \cdot 7$ \\
\hline & Muslim & 3 & 0.8 \\
\hline & Christian & 6 & 1.5 \\
\hline \multirow[t]{4}{*}{$\begin{array}{l}\text { Family income/ } \\
\text { month }\end{array}$} & $\begin{array}{l}\text { Rs.10,o00- } \\
20,000\end{array}$ & 70 & 17.5 \\
\hline & $\begin{array}{l}\text { Rs.20,000- } \\
30,000\end{array}$ & 154 & 38.5 \\
\hline & $\begin{array}{l}\text { Rs.30,000- } \\
40,000\end{array}$ & 70 & 17.5 \\
\hline & $\begin{array}{l}\text { Above } \\
\text { Rs.40,0oo }\end{array}$ & 106 & 26.5 \\
\hline Total & & 400 & 100.0 \\
\hline
\end{tabular}

From the present study, it is clear from the findings that females subjects had higher overall nutrition knowledge $(48.9 \%)$ and health awareness $(55.8 \%)$ than their male's counterparts (44\%) and (48\%) respectively. The difference in overall health awareness $\left(\mathrm{t}=3.44^{*}\right)$ and Nutritional knowledge $\left(t=2.18^{*}\right)$ between male and female found to be statistically significant $(\mathrm{p}<0.05)($ Table-5).

Table 5: Nutritional knowledge and Health Awareness of the respondents

\begin{tabular}{llccc} 
No. & $\begin{array}{l}\text { Nutritional } \\
\text { Knowledge } \\
\text { Aspects }\end{array}$ & \multicolumn{2}{c}{ Knowledge Scores (\%) } & 't' \\
& Males $(\mathbf{n}=306)$ & $\begin{array}{c}\text { Females } \\
(\mathbf{n}=94)\end{array}$ & Test \\
& Mean & Mean & \\
\hline I & Food & $51.0 \pm 19.1$ & $55.2 \pm 20.9$ & $1.75^{\text {NS }}$ \\
II & Nutrients & $28.0 \pm 22.0$ & $34.8 \pm 26.0$ & $2.29^{*}$ \\
& Combined & $43.9 \pm 15.6$ & $48.9 \pm 20.6$ & $2.18^{*}$ \\
No. & Health & Awareness Scores (\%) & 't' \\
& Awareness & Males (n=306) & $\begin{array}{c}\text { Females } \\
(\mathrm{n}=94)\end{array}$ & Test \\
& Aspects & \multicolumn{4}{c}{} \\
& \multicolumn{2}{c}{ Mean } & Mean & \\
I & Food & $64.5 \pm 25.0$ & $72.5 \pm 27.5$ & $2.55^{*}$ \\
II & Diet & $58.5 \pm 22.5$ & $67.0 \pm 22.5$ & $3.09^{*}$ \\
III & Nutrients & $29.2 \pm 23.3$ & $37.0 \pm 26.7$ & $2.55^{*}$ \\
& Combined & $47.6 \pm 17.8$ & $55.8 \pm 20.7$ & $3.44^{*}$ \\
\hline
\end{tabular}

* Significant at $5 \%$ Level, $\quad$ NS: Non-significant

Table-3 indicates that most of the dyslipidemia patients from the age group of 41-50 years (64\%) had the unfavourable level of Health Awareness. Among the gender sixty-three per cent of the male respondents had the unfavourable level of Health Awareness as compared to their female counterparts with moderate level health awareness (56\%). Unfavourable level of Health Awareness was observed irrespective of the educational and occupational status of the respondents. Further, Eighty-eight per cent of the respondents those working as staff nurses had a moderate level of nutrition knowledge. However, the association between Demographic variables and Health Awareness level on gender $\left(\chi^{2}=11.61^{*}\right)$, educational $\left(\chi^{2}=22.29^{*}\right)$ and Occupational status $\left(\chi^{2}=25.14^{*}\right)$ was found to be statistically significant at $5 \%$ level (Table 6).

Table 6: Association between Demographic variables and Health Awareness level

\begin{tabular}{|c|c|c|c|c|c|c|c|c|}
\hline \multirow{3}{*}{$\begin{array}{l}\text { Demographic } \\
\text { Variables }\end{array}$} & \multirow[t]{3}{*}{ Category } & \multirow[t]{3}{*}{ Sample } & \multicolumn{4}{|c|}{ Health Awareness level } & \multirow[t]{3}{*}{$\chi^{2}$ Value } & \multirow{3}{*}{$\begin{array}{c}\mathbf{P} \\
\text { Value }\end{array}$} \\
\hline & & & \multicolumn{2}{|c|}{ Unfavorable } & \multicolumn{2}{|c|}{ Moderate } & & \\
\hline & & & $\mathbf{N}$ & $\%$ & $\mathbf{N}$ & $\%$ & & \\
\hline \multirow{3}{*}{$\begin{array}{l}\text { Age group } \\
\text { (years) }\end{array}$} & $31-40$ & 175 & 103 & 58.9 & 72 & 41.1 & \multirow[t]{3}{*}{$2.91 \mathrm{NS}$} & \multirow{3}{*}{$\begin{array}{l}P>0.05 \\
(5.991)\end{array}$} \\
\hline & $41-50$ & 112 & 72 & 64.3 & 40 & 35.7 & & \\
\hline & $51-60$ & 113 & 60 & 53.1 & 53 & 46.9 & & \\
\hline \multirow[t]{2}{*}{ Gender } & Male & 306 & 194 & 63.4 & 112 & 36.6 & \multirow[t]{2}{*}{$11.61^{*}$} & \multirow{2}{*}{$\begin{array}{l}\mathrm{P}<0.05 \\
(3.841)\end{array}$} \\
\hline & Female & 94 & 41 & 43.6 & 53 & 56.4 & & \\
\hline
\end{tabular}


Table 6: (Continued)

\begin{tabular}{|c|c|c|c|c|c|c|c|c|}
\hline \multirow{3}{*}{$\begin{array}{l}\text { Demographic } \\
\text { Variables }\end{array}$} & \multirow[t]{3}{*}{ Category } & \multirow[t]{3}{*}{ Sample } & \multicolumn{4}{|c|}{ Health Awareness level } & \multirow[t]{3}{*}{$\chi^{2}$ Value } & \multirow{3}{*}{$\begin{array}{c}\mathbf{P} \\
\text { Value }\end{array}$} \\
\hline & & & \multicolumn{2}{|c|}{ Unfavorable } & \multicolumn{2}{|c|}{ Moderate } & & \\
\hline & & & $\mathbf{N}$ & $\%$ & $\mathbf{N}$ & $\%$ & & \\
\hline \multirow[t]{2}{*}{ Residence } & Rural & 32 & 15 & 46.9 & 17 & 53.1 & \multirow[t]{2}{*}{$2.02 \mathrm{NS}$} & \multirow{2}{*}{$\begin{array}{l}P>0.05 \\
(3.841)\end{array}$} \\
\hline & Urban & 368 & 220 & 59.8 & 148 & 40.2 & & \\
\hline \multirow[t]{6}{*}{ Educational level } & SSLC & 33 & 27 & 81.8 & 6 & 18.2 & \multirow[t]{6}{*}{$22.29^{*}$} & \multirow{6}{*}{$\begin{array}{l}\mathrm{P}<0.05 \\
(11.07)\end{array}$} \\
\hline & ITI & 71 & 47 & 66.2 & 24 & 33.8 & & \\
\hline & PUC & 44 & 31 & 70.5 & 13 & 29.5 & & \\
\hline & Diploma & 88 & 44 & 50.0 & 44 & 50.0 & & \\
\hline & Graduate & 114 & 53 & 46.5 & 61 & $53 \cdot 5$ & & \\
\hline & Post graduate & 50 & 33 & 66.0 & 17 & 34.0 & & \\
\hline \multirow{6}{*}{$\begin{array}{l}\text { Occupational } \\
\text { status }\end{array}$} & Engineering & 125 & 66 & 52.8 & 59 & 47.2 & \multirow[t]{7}{*}{$25.14^{*}$} & \multirow{7}{*}{$\begin{array}{l}\mathrm{P}<0.05 \\
(11.07)\end{array}$} \\
\hline & Technician & 131 & 80 & 61.1 & 51 & 38.9 & & \\
\hline & Security & 52 & 39 & 75.0 & 13 & 25.0 & & \\
\hline & Staff nurse & 17 & 2 & 11.8 & 15 & 88.2 & & \\
\hline & Manager & 47 & 28 & 59.6 & 19 & 40.4 & & \\
\hline & Supervisor & 28 & 20 & 71.4 & 8 & 28.6 & & \\
\hline Combined & & 400 & 239 & 59.8 & 161 & 40.2 & & \\
\hline
\end{tabular}

* Significant at $5 \%$ Level,

NS: Non-significant

Note: Figures in the parenthesis indicate Table value

From Table-4, the majority of the respondents from the age group of 41-50 years had inadequate level (69.6\%) of nutritional knowledge. The higher percentage of the male respondents had inadequate $(63 \%)$ level of nutrition knowledge when compared to their female counterparts with a moderate (52\%) level (Table 7). Inadequate level of nutrition knowledge was observed irrespective of the educational and occupational status of the respondents. Eight two percent of the respondents those working as staff nurses had a moderate level of nutrition knowledge. However, the difference in Demographic variables and Nutritional Knowledge on age group, gender, educational level and Occupational status was found to be statistically significant at $5 \%$ level $(\mathrm{p}<0.05)$.

Table 7: Association between Demographic variables and Nutritional Knowledge level

\begin{tabular}{|c|c|c|c|c|c|c|c|c|}
\hline \multirow[t]{3}{*}{ Demographic Variables } & \multirow[t]{3}{*}{ Category } & \multirow[t]{3}{*}{ Sample } & \multicolumn{4}{|c|}{ Knowledge Level } & \multirow[t]{3}{*}{$\chi^{2}$ Value } & \multirow{3}{*}{$\begin{array}{c}\text { P } \\
\text { Value }\end{array}$} \\
\hline & & & \multicolumn{2}{|c|}{ Inadequate } & \multicolumn{2}{|c|}{ Moderate } & & \\
\hline & & & $\mathbf{N}$ & $\%$ & $\mathbf{N}$ & $\%$ & & \\
\hline \multirow[t]{3}{*}{ Age group (years) } & $31-40$ & 175 & 93 & 53.1 & 82 & 46.9 & \multirow[t]{3}{*}{$7 \cdot 74^{*}$} & \multirow{3}{*}{$\begin{array}{l}\mathrm{P}<0.05 \\
(5.991)\end{array}$} \\
\hline & $41-50$ & 112 & 78 & 69.6 & 34 & 30.4 & & \\
\hline & $51-60$ & 113 & 68 & 60.2 & 45 & 39.8 & & \\
\hline \multirow[t]{2}{*}{ Gender } & Male & 306 & 194 & 63.4 & 112 & 36.6 & \multirow[t]{2}{*}{$7.21^{*}$} & \multirow{2}{*}{$\begin{array}{l}\mathrm{P}<0.05 \\
(3.841)\end{array}$} \\
\hline & Female & 94 & 45 & $47 \cdot 9$ & 49 & 52.1 & & \\
\hline \multirow[t]{2}{*}{ Residence } & Rural & 32 & 17 & 53.1 & 15 & 46.9 & \multirow[t]{2}{*}{$0.64 \mathrm{NS}$} & \multirow{2}{*}{$\begin{array}{l}\mathrm{P}>0.05 \\
(3.841)\end{array}$} \\
\hline & Urban & 368 & 222 & 60.3 & 146 & 39.7 & & \\
\hline
\end{tabular}


Table 7: (Continued)

\begin{tabular}{|c|c|c|c|c|c|c|c|c|}
\hline \multirow[t]{3}{*}{ Demographic Variables } & \multirow[t]{3}{*}{ Category } & \multirow[t]{3}{*}{ Sample } & \multicolumn{4}{|c|}{ Knowledge Level } & \multirow[t]{3}{*}{$\chi^{2}$ Value } & \multirow{3}{*}{$\begin{array}{c}\text { P } \\
\text { Value }\end{array}$} \\
\hline & & & \multicolumn{2}{|c|}{ Inadequate } & \multicolumn{2}{|c|}{ Moderate } & & \\
\hline & & & $\mathbf{N}$ & $\%$ & $\mathbf{N}$ & $\%$ & & \\
\hline \multirow[t]{6}{*}{ Educational level } & SSLC & 33 & 23 & $69 \cdot 7$ & 10 & 30.3 & \multirow[t]{6}{*}{$11.84^{*}$} & \multirow{6}{*}{$\begin{array}{r}\mathrm{P}<0.05 \\
(11.07)\end{array}$} \\
\hline & ITI & 71 & 44 & 62.0 & 27 & 38.0 & & \\
\hline & PUC & 44 & 31 & 70.5 & 13 & 29.5 & & \\
\hline & Diploma & 88 & 45 & 51.1 & 43 & 48.9 & & \\
\hline & Graduate & 114 & 60 & 52.6 & 54 & $47 \cdot 4$ & & \\
\hline & Post graduate & 50 & 36 & 72.0 & 14 & 28.0 & & \\
\hline \multirow[t]{6}{*}{ Occupational status } & Engineering & 125 & 68 & 54.4 & 57 & 45.6 & \multirow[t]{6}{*}{$35 \cdot 35^{*}$} & \multirow{6}{*}{$\begin{array}{r}\mathrm{P}<0.05 \\
(11.07)\end{array}$} \\
\hline & Technician & 131 & 69 & 52.7 & 62 & $47 \cdot 3$ & & \\
\hline & Security & 52 & 43 & 82.7 & 9 & $17 \cdot 3$ & & \\
\hline & Staff nurse & 17 & 3 & $17 \cdot 7$ & 14 & 82.3 & & \\
\hline & Manager & 47 & 34 & 72.3 & 13 & $27 \cdot 7$ & & \\
\hline & Supervisor & 28 & 22 & 78.6 & 6 & 21.4 & & \\
\hline Combined & & 400 & 239 & 59.8 & 161 & 40.2 & & \\
\hline
\end{tabular}

* Significant at 5\% Level, NS: Non-significant

Note: Figures in the parenthesis indicate Table value

\section{DISCUSSION}

Consciousness about appropriate nutrition, food nutritional value and good eating habits can make a difference in the wellbeing of the society and country as a whole. Nutritional deficiencies can lead an entire nation as infertile. ${ }^{12}$ the relationship between nutrition and health is one of the primary antecedents to good health and well-being. In a vast country like India, although the general trend indicates an increase in common adverse factors, there are regional differences as well, influenced by diet, culture, socioeconomic status, etc. In this sense, one aspect that can improve the quality of life is increasing the ability of a population to understand health-related phenomena. ${ }^{13}$ The existing study suggests that the majority of dyslipidemia patients had unfavourable health awareness and inadequate nutritional knowledge. The knowledge of health outcomes, in particular regarding NonCommunicable diseases (NCDs) and their risk factors, may be useful in avoiding the onset of a disease..$^{13}$ Concerning food, knowledge of what should be eaten and the awareness of the importance of healthy food habits are the first steps in altering eating behaviour. Knowledge does not stimulate change but instead acts as an important tool when people desire to change, given that knowledge rarely anticipates a behavioural change. ${ }^{14}$ The individual nutrition knowledge may favour healthy food consumption and thus promote changes in food habits that may reduce the risks of developing Communicable diseases (NCDs). ${ }^{15}$ Inadequate educational level decline knowledge level, differences in knowledge between socio-demographic status and men knowledge is poorer than women's. ${ }^{13}$ The factors like age, sex, level of education and socioeconomic status are familiar to control the nutrition knowledge. ${ }^{17}$ Females have higher levels of nutrition knowledge than male counterparts and this variation has been recognized to their more predominant role in purchasing of foodstuffs and preparation or a lower concern in nutrition by males. ${ }^{18}$ Our results showed that female respondents had higher overall nutrition knowledge and health awareness $(55.8 \%)$ than their male counterparts. The main part of nutrition knowledge to the overall consumption of safe food is considered to be complex and is determined by the interaction of many demographic and ecological factors. ${ }^{16}$ However, a better understanding of the association between nutrition knowledge and food intake is important as promising evidence that supports to a strong connection between low health literacy, poor management of chronic disease and improved health costs. ${ }^{18}$

\section{CONCLUSION}

The presents study showed that Health awareness and nutritional knowledge among female Dyslipidemia subjects found higher than male subjects however found inadequate. Gender difference in both health awareness and nutritional knowledge found statistically significant. Creating health awareness and nutritional knowledge alone may not be an adequate amount of to progress health status in patients 
with dyslipidemia. Efforts including patient education and counselling through a multi-team approach may be required. Mass media need to be strengthening in improving health awareness and nutritional knowledge of Dyslipidemia subjects. Periodical training programmes on health and nutrition need to be imparted which leads to a better lifestyle, less incidence of disease and socio-psychological wellbeing.

\section{ACKNOWLEDGEMENTS}

The authors wish to express their thanks to the Chief of Medical Services of Bharat Electronics Limited, Hindustan Aeronautics Limited and BEML Limited companies hospitals Bangalore, Karnataka for supporting to complete this research.

\section{Source of Funding: Nil}

\section{Conflict of Interest}

No conflict of interest pertaining to this article was reported.

\section{REFERENCES}

1. Shamsi Y, Kumar H. A Randomized, Double-Blind Study To Evaluate The Pharmacological Effect Of A Polyherbal Drug (Lipotab) In Managing Dyslipidemia. Int J Curr Res Rev 2012;4(6); 20-29.

2. Gupta R. Burden of coronary heart disease in India. Indian Heart J 2005;57:632-638.

3. World Health Organization, Diet, nutrition and the prevention of chronic diseases: Report of a Joint WHO/FAO expert consultation; WHO: Geneva, Switzerland, 2003.

4. Nicklas TA, Hayes D. Position of the American Dietetic Association: nutrition guidance for healthy children ages 2 to 11 years. J Am Diet Assoc 2008;108;1038-1047.
5. Joy-Telu HE, Malcolm T. Teaching/learning methods and students' classification of food items. Health Educ 2011;111;66-85.

6. Kalpana CA. Development of an interactive website on metabolic syndrome and its impact on obese adolescent girls. Int $\mathrm{J}$ Cur Res Rev 2017;9(3);34-38.

7. Dallongeville J, Marecaux, N. Cottel, D. Bingham, A. Amouyel, P. Association between nutrition knowledge and nutritional intake in middle-aged men from Northern France. Public Health Nutr 2001;4;27-33.

8. Gates G, McDonald M. Comparison of dietary risk factors for cardiovascular disease in African-American and white women. J Am Diet Assoc 1997;97;1394-1400.

9. Furst T, Connors M, Bisogni CA, Sobal J, Falk LW. Food choice: A conceptual model of the process. Appetite 1996;26;247-265.

10. Paquette MC. Perceptions of healthy eating: State of knowledge and research gaps. Can J Public Health 2005;96(3);S15-S21.

11. Ghvanidze S, Velikova N, Dodd TH, Oldewage-Theron W. Consumers' environmental and ethical consciousness and the use of the related food products information: The role of perceived consumer effectiveness. Appetite 2016;107;311-322.

12. Barbosa BL, Vasconcelos SML, dos Santos Correia LO, Ferreira RC. Nutrition knowledge assessment studies in adults: a systematic review Ciência \& Saúde Coletiva. 2016; 21(2); 449-462.

13. Chapman KM, Ham JO, Liesen P, Winter L. Applyingbehavioral models to dietary education of elderly diabetic patients. J Nutr Educ Behav 1995;27(2);75-79.

14. Wardle J, Parmenter K and Waller J. Nutrition knowledge and food intake. Appetite. 2000;34; 269-275.

15. Parmenter K, Waller J and Wardle J. Demographic variation in nutrition knowledge in England. Health Educ Res 2000; 15;163-174.

16. Hendrie G, Coveney J and Cox D. Exploring nutrition knowledge and the demographic variation in knowledge levels in an Australian community sample. Public Health Nutr 2008;11;1365-1371.

17. Eichler K, Wieser S, Brugger U.The costs of limited health literacy: a systematic review. Int J Public Health 2009;54;313-324.

18. Vernon JA, Trujillo A, Rosenbaum S. Low Health Literacy: Implications for National Health Policy. Washington, DC: Department of Health Policy, School of Public Health and Health Services, The George Washington University, 2007. 